J. of Korean Inst. of Resources Recycling

Vol. 21, No. 3, 2012, 3-14

》總 說 $\ll$

中國手 都市鑛山 再資源化產業 ${ }^{\dagger}$

中吳在賢 $\cdot$ 金俊秀* ·文碩敏 $* * \cdot$ 閔芝源 $* * *$

延世大學校 名譽敉授, *韓國地質資源研究院, **ACN, ***韓國資源리싸이클링學會

\title{
Recycling Industries of Urban Mine Resources in China ${ }^{\dagger}$
}

\author{
^Jae-Hyun Oh, Joon-Soo Kim*, Suk-Min Moon** and Ji-Won Min*** \\ Professor Emeritus of Yonsei University, \\ *Korea Institute of Geoscience and Mineral Resources, **ACN, \\ ***The Korean Institute of Resources Recycling
}

\section{요 약}

중국의 도시광산 재자원화산업을 파악 - 검토하기 위하여 $\operatorname{ELV(ㅅㅏㅇㅛㅇㅎㅜㅈㅏㄷㅗㅇㅊㅏ),~E-waste(Waste~Electric~Electronic~Equipment)~ㅁㅣㅊ~}$ 비철금속의 리싸이클링을 조사하였다. 중국의 자동차 판매대수가 1,000 만대를 넘어서고, 폐차대수도 증가하고 있으나 리싸이클링은 원활하지 못하다. 중국 도시의 가전 보유량은 선진국 수준으로 농촌과의 격차가 크다. 세계 E-waste의 많은 량이 중국으로 유입되 어 세계의 E-waste 리싸이클링센터를 형성하고 있다. 비철금속의 소비량은 계속 증가하고 있지만 리싸이클링 수준은 낮다.

주제어 : 중국, ELV, E-waste, 비철금속, 리싸이클링

\begin{abstract}
In order to review the recycling status of urban mine resources in China, recycling of ELV(End of Life Vehicles), Ewaste(WEEE) and nonferrous metals were surveyed. Number of the sales volume of the new vehicles were over more than ten million and number of discharge vehicles are increasing now. However, recycling system has not been managed smoothly in China. Though usage of home appliances in urban is similar with advanced countries, there are significant differences in rural community. In the other hand, China is the country with the largest E-waste import in the world. Production and consumption of the nonferrous metals are increasing year by year in China, but recycling of metals is not enough.
\end{abstract}

Key words: China, ELV, E-waste, nonferrous metals, recycling

\section{1. 머리말}

중국에서 폐구물자(廢舊物資)의 회수는 계획경제시대 (1950년대)부터 행하여지고 있었다. 폐구물자는 사람의 산업활동 또는 일상생활에서 발생하는 폐기물 중에서 사용가치가 남아있는 것을 말한다. 당시 경제발전의 초 기였던 중국에서는 폐구물자를 적극적으로 회수하고 그 재이용의 확대는 경제발전의 추진에 있어서 중요한 의

†2012년 4월 3일 접수, 2012년 5월 11일 1차수정
2012년 5월 25일 수리
*E-mail: kirr@kirr.or.kr

의를 가지고 있었다. 1958 년 周恩來 총리의 발언 1 즉 ‘폐구물자의 회수·재이용은 자원을 절약하면서 국가를 건설하는 방책으로 유익한 사업이다'는 유명하다. 이 사 고(思考)는 현 정부로 계승되어 쓰레기 처리가 아니고 미이용 자원의 유효이용을 추진하는 재생자원 회수시스 템이 정부 주도로 40 년 이상 형성되어 왔다. 한편, 중 국은 세계의 리싸이클링 일대 거점이 되고 있고, 다량 의 재생자원이 중국으로 유입되고 있음이 잘 알려져 있 다. E-waste 세계 발생량의 $80 \%$ 가 아세아로 유입되고 있고, 그 중 $90 \%$ 가 중국으로 유입되고 있다. 중국이 불법적으로 수입한 E-waste ${ }^{2)}$ 는 1990년 100만톤, 2000 
년 1,800 만톤, 2010 년에는 3,000 만톤에 이르고 있다. 이와 같이 중국은 환경보전보다는 자원 확보면에 높은 비중을 두고 있다. 이러한 관점에서 본 고에서는 중국 의 $\operatorname{ELV}$ (사용후자동차), E-waste 및 비철금속, 소위 도 시광산자원의 리싸이클링 개략을 파악하고자 하였다.

\section{2. $\mathrm{ELV}$ 의 리싸이클링}

\subsection{ELV 리싸이클링의 개략}

Table $1^{3)}$ 은 중국의 승용차보유대수, 판매대수, 폐차대 수 등을 표시한 것이고, Table $2^{4)}$ 는 중국 승용차 보유
대수, 폐차대수, 폐차장수 등을 표시한 것이다.

중국의 자동차 판매대수는 이미 세계 1 위로 성장했고, 수년 내로 폐차대수도 대폭 증가할 것으로 예상된다. 중 국의 자동차 판매대수는 WTO 가입 직후인 2002년에 는 322 만대 정도였으나, 1,000 만대를 돌파하기까지는 겨 우 7년이 소요되었다(년 평균 성장률 $22.6 \%$ ). 미국이 1920년의 모터리제이션(motorization) 이후, 1,000 만대를 판매하기까지 40 년 이상이 소요된 것을 고려한다면 중 국은 금후 급속한 성장이 예상되고, 급격한 폐차증가도 쉽게 추정된다. Table 2에 의하면 2010년도 승용차 보 유대수가 75,000 천대, 폐차대수가 4,800 천대로 이는

Table 1. Amount of vehicles(passenger), sales volume, scrapped vehicles in China

\begin{tabular}{|c|c|c|c|c|c|}
\hline 구분 & 승용차 보유 대수(만대) & 판매대수 (만대) & 폐차대수 (만대) & 폐차율 (\%) & 통계상의 폐차대수(만대) \\
\hline 2002년 & $2,053.17$ & 322.49 & 84.11 & 4.1 & 41.45 \\
\hline 2003년 & $2,382.93$ & 439.70 & 127.12 & 5.33 & 95.68 \\
\hline 2004년 & $2,693.71$ & 506.82 & 213.58 & 7.93 & 54.15 \\
\hline 2005년 & $3,159.66$ & 577.77 & 127.96 & 4.05 & 56.2 \\
\hline 2006년 & $3,697.35$ & 722.14 & 207.23 & 5.6 & 38.06 \\
\hline 2007년 & $4,358.36$ & 879.12 & 249.52 & 5.73 & 35.06 \\
\hline 2008년 & $5,099.61$ & 938.05 & 237.78 & 4.66 & - \\
\hline
\end{tabular}

출처 : 중국자동차공업협회

Table 2. The volume of scrapped vehicles in China

\begin{tabular}{|c|c|c|c|c|}
\hline Year & Number of passenger cars & Scrapped vehicles & Junkyard companies & Average scrapped cars \\
\hline 2000 & $16,089,100$ & 363,613 (est) & $356($ est) & 1,021 \\
\hline 2001 & $18,020,408$ & 479,342 (est) & $356($ est) & 1,346 \\
\hline 2002 & $20,531,700$ & 414,500 & $356($ est) & 1,165 \\
\hline 2003 & $23,829,254$ & 956,800 & $356($ est) & 2,687 \\
\hline 2004 & $26,937,137$ & 541500 & $356($ est) & 1,521 \\
\hline 2005 & $31,596,629$ & 562,000 & $356($ est) & 1,578 \\
\hline 2006 & $36,973,531$ & 380,060 & $356($ est) & 1,067 \\
\hline 2007 & $43,583,550$ & 350,600 & $356($ est) & 984 \\
\hline 2008 & $55,000,000$ (est) & $2,000,000($ est) & $356($ est) & 5,167 \\
\hline 2009 & $67,800,000$ (est) & $3,000,000($ est) & 356 & 8,426 \\
\hline 2010 & $75,000,000$ (est) & $4,800,000($ est) & 356 & 13,483 \\
\hline
\end{tabular}

Source : National Bureau of Statistics of China. * (est) : estimated amount

J. of Korean Inst. Resources Recycling Vol. 21, No. 3, 2012 


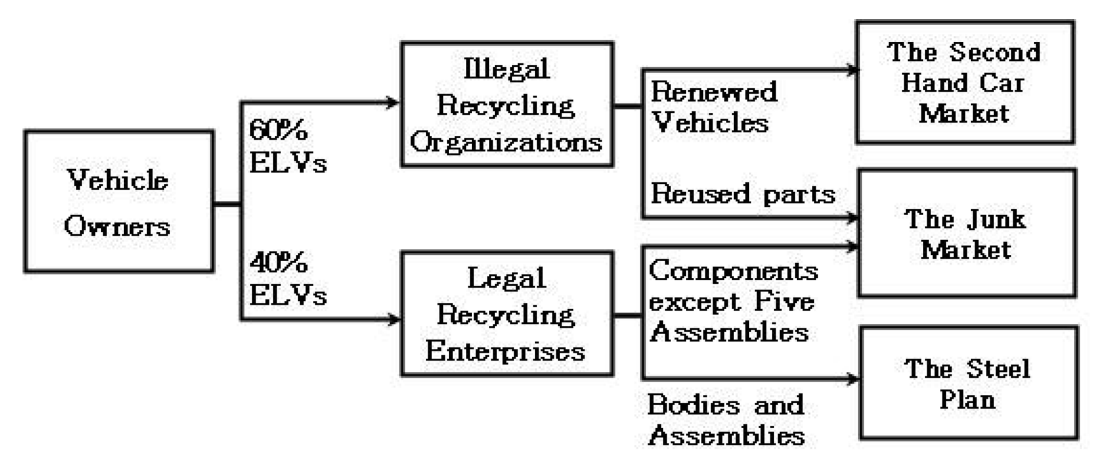

Fig. 1. Flow channels of ELVs in China.

Table 3. Outline of the ELV management measure in China

\begin{tabular}{|c|c|}
\hline 회수대상 & $\begin{array}{l}\text { · 폐차기준에 달한 차량 } \\
\text { · 국가자동차운행안전조건과 배기기준에 불합격된 기동차량 }\end{array}$ \\
\hline $\begin{array}{l}\text { 회수기업의 } \\
\text { 설립조건 }\end{array}$ & $\begin{array}{l}\text { · 국가는 자동차회수업의 전문적 관리를 하기 때문에, 회수기업의 인정제도를 실시한다. } \\
\text { · 조건 : 자본금 } 50 \text { 만인민원 이상, 해체장면적 } 5,000 \text { 이상, 필요한 해체설비와 소방설비의 설치, 년간 } \\
\text { 회수 분해능력 } 500 \text { 대 이상, 작업원 } 20 \text { 인 이상, 전문기술원 } 5 \text { 인 이상, 폐차(5대품목)의 판매· } \\
\quad \text { 재조립 등의 위법기록이 없을 것, 국가 환경기준에 적합할 것 }\end{array}$ \\
\hline $\begin{array}{l}\text { 폐차의 } \\
\text { 흐름 }\end{array}$ & $\begin{array}{l}\text { - 폐차 보유기업/개인은 공안부문에 신고하여 자동차폐차증명을 신청한다. } \\
\text { · 폐차회수기업은 자동차폐차증명에 따라 폐차보유기업/개인에게 폐차회수증명을 발행한다. } \\
\text { · 폐차 보유기업/개인은 폐차회수증명을 공안부문에 제출하여 폐차등록을 행한다. }\end{array}$ \\
\hline
\end{tabular}

2006 2007년경의 일본의 경우와 비슷한 상황을 보여준 다. Table 1과 Table 2는 출처를 달리하여 약간의 차이 는 있으나 대체로 비슷한 통계치를 보여주며, Table 2의 폐차대수는 Table 1의 통계상의 폐차대수와 같다.

2008년 현재, 중국의 자동차 보유대수는 약 5,100만 대이고 1년 전과 비교해서 700 만대 이상 증가하고 있 다. 그리고 폐차는 약 238만대로 되어 있지만, 통계상 의 폐차대수는 그 $1 / 5$ 에도 못 미치는 상황이다. 즉 대 도시와 지방도시의 빈부격차가 심하여 대도시의 폐차가 중고차로서 유통되는 예가 많아 실제로 해체공장으로 유통되는 폐차는 아주 적다(Fig. 1 ${ }^{4}$ 참조).

현재, 중국 전국에 $\mathrm{ELV}$ 해체공장이 356사 있고 각 지역의 기술수준, 공장규모의 격차가 크며 지방도시에 있는 해체공장의 환경오염은 심각하다.

\section{2. $\mathrm{ELV}$ 리싸이클링에 관한 정책과 제도 ${ }^{5)}$}

중국에서는 위법(違法) 폐차의 회수 · 전매 및 폐차부 품에 의한 완성차의 개조 - 조립에 의한 교통안전문제를 중시하고 있다. 2001년 6월에는, 國務院이 중화인민공화 국 폐기자동차 회수관리 방법(제307호령)을 공포하였다.
이 307호령이 현재 폐기자동차의 회수·리싸이클링에 있 어서 유일한 법규제로 되어 있고, 재조립을 방지하기 위 한 시장규제에 목적을 두고 있다(Table 3 참조 ${ }^{1)}$ ).

구체적으로는 5대품목(엔진, 스티어링장치, 트랜스미 션, 프레임, 차축)의 reuse가 금지되어 있고, 해체기업에 서는 이들 부품의 기능을 파괴해서 철 스크랩으로서 리 싸이클하지 않으면 안 된다. 또 택시, 버스 및 트럭 등 의 상업차량은 정해진 년수(8 10년)를 주행하면 강제적 으로 폐차 처리해야 하였지만, 그 후 철폐되어 차검(車 檢)의 기준에 합격하면 몇 년이고 주행이 가능하게 되 어 있다. 5대 품목 중 “엔진”도 해금되어, 중고엔진의 판매 및 재제조사업이 가능하게 되었다.

한편 2006년 2월 6일에 국가발전개혁위원회, 과학기 술부 및 국가환경보호총국은 「자동차제품 회수이용기 술 정책」을 공포하였다. 이 정책의 주요내용은 다음과 같다.

(1) 자동차의 회수이용 목표

2010 년부터 자동차리싸이클율을 $85 \%$ 로 하고, 자원으 로서의 이용율을 $80 \%$ 이상 충족해야 한다. 2008 년부터 자동차메이커 및 판매회사는 자동차의 회수이용율에 관 
한 정보등록을 하여 상기의 회수이용목표를 준수한다(제 1단계). 2012년부터는 리싸이클율을 90\%로 높인다(제2 단계). 최후의 2017년부터는 리싸이클율을 $95 \%$, 자원으 로서의 재이용율을 $85 \%$ 이상으로 한다(제 3 단계).

(2) 자동차메이커의 책무

자동차메이커는 자동차의 설계 - 제조단계부터 자동 차리싸이클을 고려해서 해체하기 쉬운 재료 및 기술을 채용할 필요가 있다. 재료의 선정에 있어서는 소형 또 는 경량화에 노력하며, 재생 가능한 부품 또는 재료를 이용하여 재료의 이용율을 높인다. 재료에 함유된 납, 수은, 카드뮴 및 6가크롬 등의 사용을 제한하고 유해물 질의 사용량 등을 부품에 표시해야 한다.

(3) 폐차 회수 처리업자(해체업자)의 책무

환경보호행정기관으로부터 경영허가를 받아야 한다. 폐기자동차 회수관리방법(국무원, 2001년)의 규정에 따 라 자동차의 회수처리를 해야 한다.

(4) 국가의 책무

폐차회수 network를 구축하고 관련 행정기관 및 자 동차메이커와 공동으로 관련정책의 정비·개선을 행한다.

\subsection{ELV 해체리싸이클링 프로세스 사례 -瀋陽秋實 報廢汽車回收有限公司 -}

동북지방을 대표하는 중국 제 5 의 거대도시인 심양(瀋 陽)시에서는 1990 년대까지는 시내에 많은 해체업체가 가동하고 있었으나 1990년대 후반 이후에는 정책에 의 하여 업체의 통폐합이 이루어졌다. 2004년에는 정부인 증의 해체공장 1 개사만의 체제가 되었고 현재는 제 307 호령에 의거한 폐차의 회수 · 해체 처리가 시행되고 있 다. 그 유일의 인증공장은 瀋陽秋實報廢汽車回收有限公 司이다. 2011년 7월 12일 필자는 이 공장을 방문하여 趙學光 부사장의 회사설명과 현장안내를 받았다. 종업원은 현장 80 명, 사무실 40 명, 4.9 만 $\mathrm{m}^{2}$ 의 폐차보관야드, 4.0 만 $\mathrm{m}^{2}$ 의 해체처리공장을 갖춘 거대공장이다. 넓은 폐차 보관 야드에는 승용차, 버스, 트럭은 물론 군용차(photo 1,2 참 조)도 볼 수 있었다. 심양지역의 군용차는 전부 이곳으 로 오게 되어 있다. 그래서인지 멀쩡하게 보이는 군용차 가 보관야드도 모자라 차도에도 보관되어 있다. 이 멀쩡 하게 보이는 군용차가 중고차로서 유통되지 않고 해체 한다는 것이 아깝기도 하였다.

심양시는 인구 600 만, 약 100 만대의 자동차를 보유하고 있다. 추정치이지만 년간 약 4 만대의 폐차가 발생한다. 이 공장의 처리대수는 16,000대(2010년) 정도로서 발생 폐차 의 $40 \%$ 가 이 공장에서 해체 처리되고 나머지는 위법해체

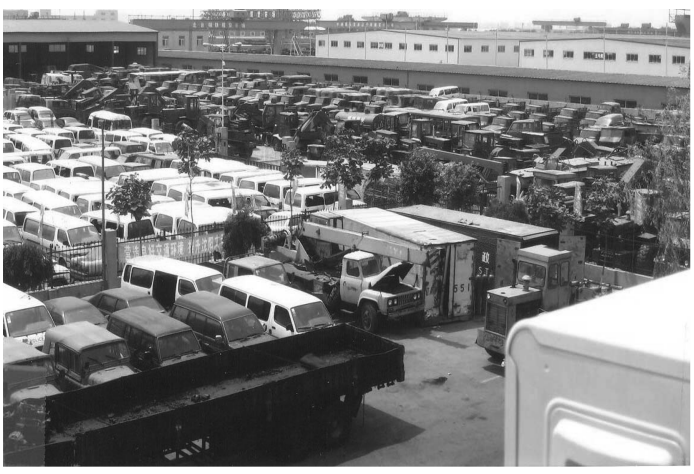

Photo 1. Military ELV on the yard(right site).

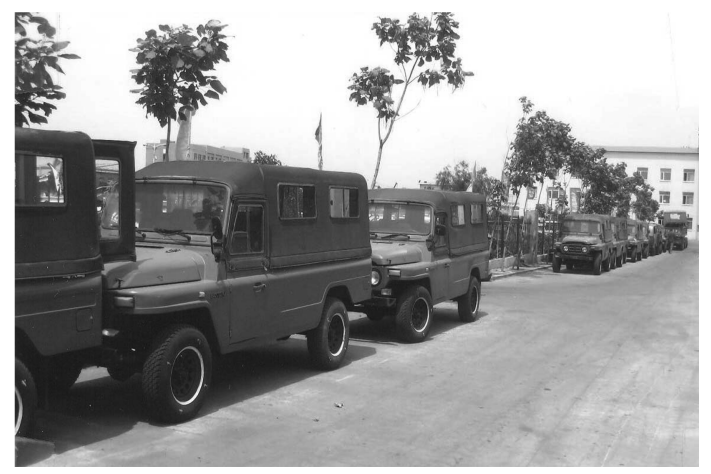

Photo 2. Military ELV on the road.

업자에 의하여 처리되고 있다. 위법처리업자와 폐차확보를 경쟁해야 하므로 폐차의 구매가격이 높아진다. 현재 이 공 장에서는 5대의 견인차로 폐차를 확보, 구매하고 있으며 구매가격이 승용차의 경우 1,400 元/톤, 트럭은 2,300 元/톤 이라고 한다. 이 가격은 주변도시보다 5 배나 높은 수준 이다. 이 회사의 년 매출고가 2,000萬元(2010년)을 약 간 넘을 정도라고 한다. 2,000 萬元 $/ 16,000$ 대로 계산하니 까 1,250 元/대로 구매가격에 못 미치고 있다. 이 회사의 경영 노하우는 어디에 있는지 궁금하다.

Fig. $2^{1)}$ 는 중국의 일반적인 ELV 처리흐름이다. 이 공장도 이와 다를 바가 없다. 먼저 탱크에 남아있는 폐 유를 회수하고, 가스용접기에 의해서 수작업으로 해체 한다. 다음에 타이어, 철스크랩, 플라스틱, 부품 등으로 분류 - 선별한다. 철스크랩은 本溪口제철소에 판매한다. 우레탄, 스폰지, 가죽 등의 내장재는 매립한다. 매출은 거의 철 스크랩이 차지하고 중고부품의 판매액은 매우 낮다. 사진(photo 3, 4)에서 보는 것처럼 ELV 해체작 업장은 노천의 마당으로 되어 있고 포장이 안 되어 있 기 때문에 유류에 의한 토양오염이 되고 있다. 프레온 


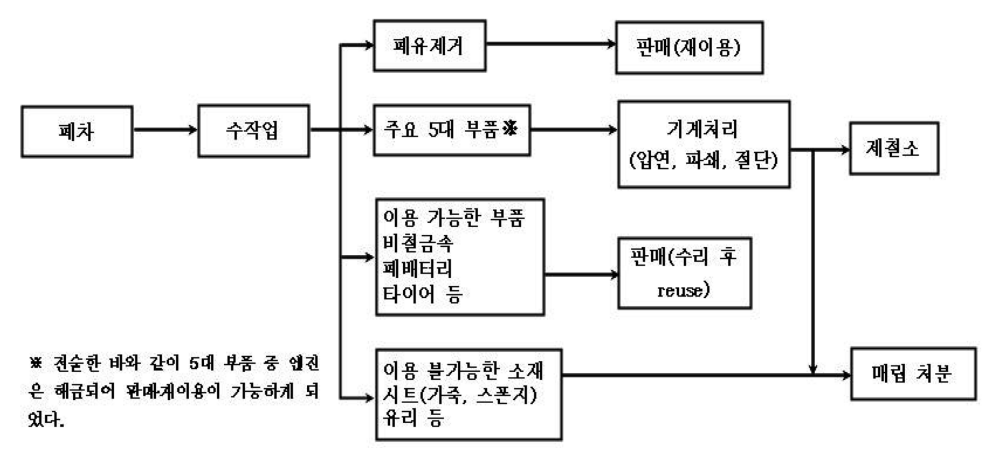

Fig. 2. Processing flow of the ELV in China.

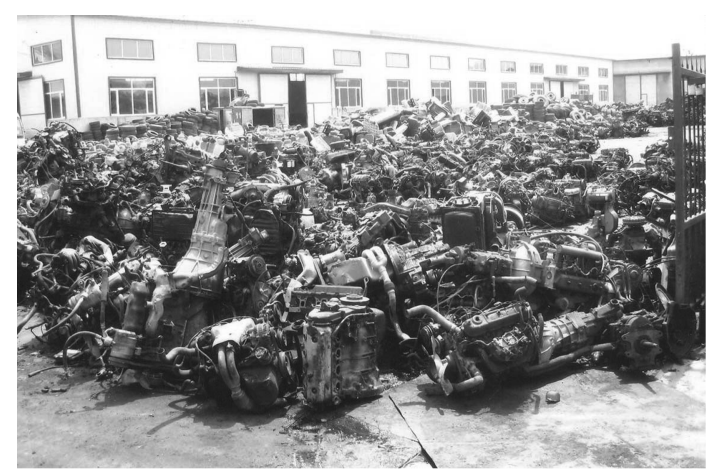

Photo 3. Used engines recovered from ELV.

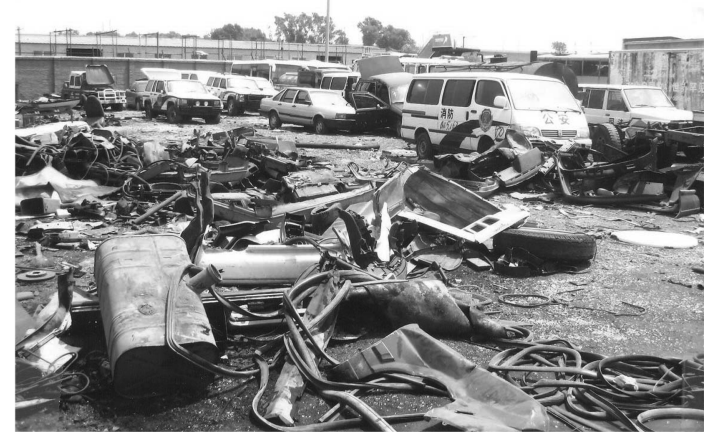

Photo 4. Dismantling working yard.

가스의 회수도 안하고 있다. 경영자의 환경보전에 대한 의식은 높지만 현장의 설비 및 기술이 따르지 않는다. 趙부사장의 설명에 의하면 현장 해체작업은 청부체제 로 하기 때문에 능률적이라고 한다. 도시에서 사용된 자 동차가 폐기 년한 직전에 내륙지역 혹은 농촌 등으로 유출되고 있다. 이 현상은 선진지역인 도시에는 폐차수 가 부족하고, 정비가 지연되고 있는 내륙부의 개발도상
지역에 있어서는 폐차가 대량 발생한다. 이들 폐차가 최 종적으로 어떻게 처리·리싸이클되고 있는지 불분명하다.

\section{E-waste의 리싸이클링}

\subsection{E-waste recycling 의 개략}

중국은 세계 리싸이클링의 일대 거점이 되고 있고 다 량의 재생자원이 중국으로 유입되고 있음이 잘 알려져 있다(Fig. 32)참조). E-waste 세계 발생량의 $80 \%$ 가 아 세아로 유입되고 있고 그 중의 $90 \%$ 가 중국으로 유입되 고 있다. 중국이 불법적으로 수입한 E-waste는 1990년 100 만톤, 2000년 1,800만톤, 2010년에는 3,000만톤에 이르고 있다.

한편, 국내에서는 경제발전과 소득항상에 의하여 사 용된 내구소비재가 대량 발생하는 시기가 도래하여 리 싸이클링이 새로운 문제로 대두되고 있다. 즉 도시지역 에서는 대량의 폐기제품이 발생하고 있지만, 적정한 처 리 · 리싸이클이 이루어지고 있지 않아 자원의 낭비와 환경오염이 걱정된다.

Table 4 는 중국의 100 세대 당 가전제품 보유대수를 표시한 것이다. 2005년 도시지역 100세대 당 보유대수 는 칼라TV 134.8대, 냉장고 90.8대, 세탁기 95.5대, 에 어컨 80.7 대에 달하고 있다. Table $5^{1}$ 는 중국 국가환경 보호총국이 추계(2004년)한 가전의 보유량과 폐기량을 표시한 것이다.

Table $6^{2}$ )은 Guo Zueyi(郭學益)에 의해서 추계(2009 년)한 가전의 보유량과 폐기량을 표시한 것이다. 5년간 (2004 2009)에 보유량은 2 3배로 늘었고 폐기량은 $5 \sim 10$ 배로 증가였음을 보여주고 있다. Fig. 4에는 현재 (2007년) 폐가전의 유통루트를 도시하였다. 


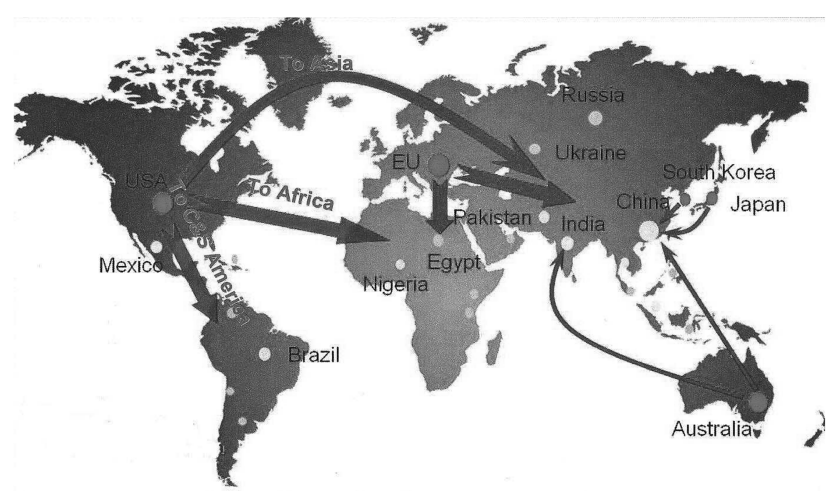

Fig. 3. E-waste transportation on the world.

Table 4. Amount of home appliances per 100 homes in China

\begin{tabular}{|c|c|c|c|c|c|c|c|c|}
\hline \multirow{2}{*}{} & \multicolumn{2}{|c|}{1990 년 } & \multicolumn{2}{c|}{ 1995년 } & \multicolumn{3}{c|}{2000 년 } & \multicolumn{2}{c|}{2005 년 } \\
\cline { 2 - 9 } & 농촌 & 도시 & 농촌 & 도시 & 농촌 & 도시 & 농촌 & 도시 \\
\hline 칼라TV & 4.72 & 59.04 & 16.92 & 89.79 & 48.74 & 116.56 & 84 & 134.8 \\
\hline 흑백TV & 39.72 & 52.36 & 63.81 & 27.97 & 52.97 & - & 21.77 & - \\
\hline 냉장고 & 1.22 & 42.33 & 5.15 & 66.22 & 12.31 & 80.13 & 20.1 & 90.72 \\
\hline 세탁기 & 9.12 & 78.41 & 16.9 & 88.97 & 28.58 & 90.52 & 40.2 & 95.51 \\
\hline 에어컨 & - & 0.34 & 0.18 & 8.09 & 1.32 & 30.8 & 6.4 & 80.67 \\
\hline
\end{tabular}

출처 : 중국통계연감

Table 5. Generation of the waste home appliances in China (2004)

\begin{tabular}{|c|c|c|}
\hline & 보유량(억대) & 폐기량(만대) \\
\hline TV & 3.5 & 500 \\
\hline 냉장고 & 1.3 & 500 \\
\hline 세탁기 & 1.7 & 500 \\
\hline 컴퓨터 & 0.2 & 500 \\
\hline 휴대전화 & 1.9 & $>1,000$ \\
\hline
\end{tabular}

출처 : 국가환경보호총국의 추계에 의한 新華社(2005년 9월 22일)의 보도자료.

주 : 년간 111 만톤의 E-waste가 발생하며, 생활쓰레기 발생량의 $1 \%$ 를 차지한다.

Table. 6. Amount of home appliances and of discharged home appliances in China (2009)

\begin{tabular}{|c|c|c|}
\hline & 보유량(억대) & 폐기량(만대) \\
\hline TV & 6.7 & 1200 \\
\hline 컴퓨터 & 1.5 & 4000 \\
\hline 휴대전화 & 6.9 & 500 \\
\hline 냉장고 & 3.5 & 100 \\
\hline 에어컨 & 2.0 & 100 \\
\hline 세탁기 & 2.9 & \\
\hline
\end{tabular}

J. of Korean Inst. Resources Recycling Vol. 21, No. 3, 2012 


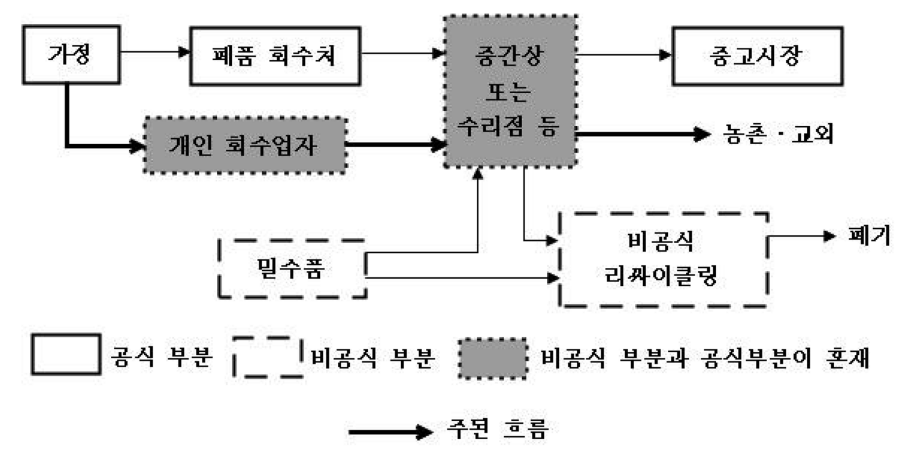

Fig. 4. Collection and recycling system of the E-waste in China.

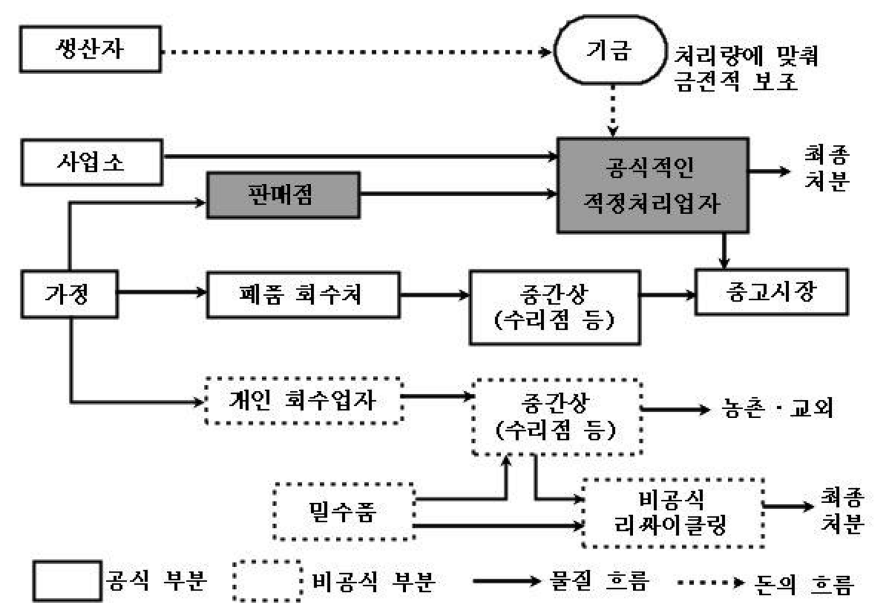

Fig. 5. Collection and recycling system plan of the E-waste in the future in China.

\subsection{E-waste 리싸이클링 정책과 제도 ${ }^{1)}$}

중국정부는 국내에서 발생하는 폐가전의 적정처리 · 리싸이클링을 추진하기 위하여 2002년부터 국가발전개 혁위원회가 중심이 되어 리싸이클링법·제도의 검토를 시작하였다. 2005년 4월에 개정된 고형폐기물 환경오염 방지법에서 처음으로 생산자책임제도가 도입되어서 제품의 생산자, 판매자, 수입자는 사용자가 발생시킨 고 형폐기물의 오염을 방지해야 되는 책임이 있다라고 하 여, E-waste에 관한 생산자 책임을 명문화 하였다. 중 국판 가전리싸이클법인 폐구가전 회수처리 관리조례는 국가발전개혁위원회의 위탁을 받아 중국가전협회와 주 류 가전 제조메이커가 공동으로 초안을 작성한 것이다. 폐구가전은 폐가전(폐기를 맞이한 가전)과 구가전(중고 가전)을 지칭하고 있다. 이 법은 2011년 1월 1일부터 시행될 예정이었는데 이 법에서 구상하고 있는 폐가전 리싸이클링시스템을 Fig. 5에 도시하였다.
이 관리조례의 대상품목은 $\mathrm{TV}$, 냉장고, 세탁기, 에어 컨 및 컴퓨터의 5 품목이다. 가전의 생산자, 판매자 및 $\mathrm{AS}$ 기관은 폐구가전의 회수의무를 가지며 사용 년한에 달한 폐구가전을 다원화루트로 회수해서 처리능력이 있 는 인정기업에 의탁하여 환경기준을 준수한 처리 - 리 싸이클을 해야 한다. 그리고 reuse의 경우는 인정기업에 서 검사를 받고 중고품으로서 기준을 충족해야 시장에 서 매매할 수 있다(제11조). 이 조례에서 가장 관심이 큰 규정은 국가폐구가전회수처리를 위하여 기금을 설립 하고 회수 처리비용을 보조한다이다. 정부는 폐가전 리 싸이클을 위하여 특별지출기금을 설립하여 리싸이클기 업의 운영에 정책상의 지원을 하고 제조메이커는 1 대 출하 때마다 그 가전 1대에 소요되는 회수, 리싸이클 비용을 부담해야 한다. 이 외에 2003년 1월부터 시행된 청결생산촉진법과 순환경제촉진법(2009년 1월 시행)도 성에너지와 리싸이클링에 관련된 규정을 정하고 있다. 


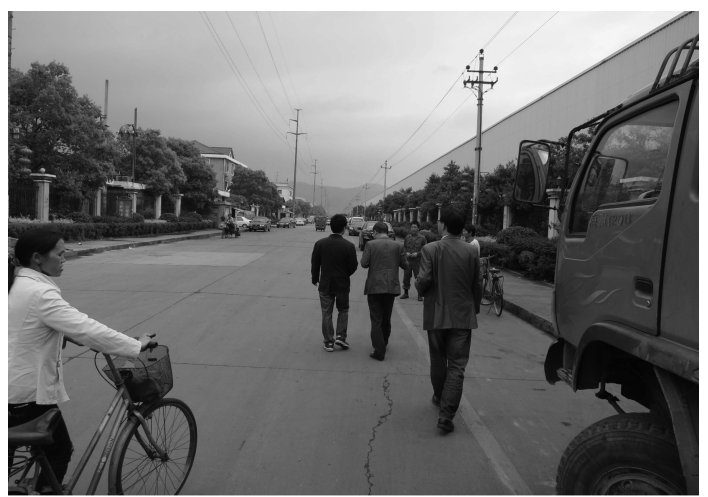

Photo 5. Taizhou recycling complex.

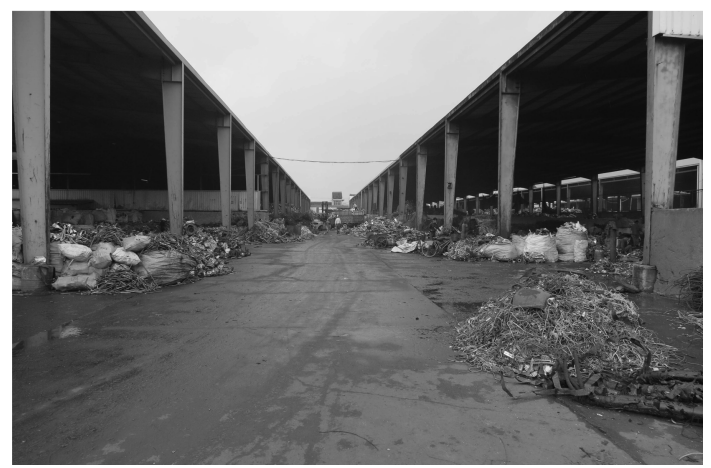

Photo 6. Inside view of the factory( 台州大創金屬).

\section{3. 절강성 태주시(浙江省 台州市) 금속재생산업단지}

절강성 태주(TAIZHOU)시 금속재생산업단지는 국가 지정 자원재생순환경제산업단지 중 하나로, TAIZHOU 항에서 17 킬로미터 떨어진 곳에 위치하고, 단지면적은 36 만평(약 120 만 평방미터)이며 2002년 9월 착공하여 2003년말 완공되었다. 일직선으로 된 넓은 도로 양쪽에 리싸이클링업체가 입주하고 있다(photo 5).

이 단지의 처리량은 현재 약 250 만톤 년 정도이며, 34 개 자원재생 지정업체가 입주해있다. 이중 19 개 업체 는 해외합작기업이다. 수입된 폐전자제품 및 금속스크 랩의 해체작업을 주로 하고 있으며, 약 2 만명이 넘는 유동인구에게 일자리를 제공하며, 1,000 개에 달하는 단 지 주위 소규모 영세업체를 포함하면 5 만명이 넘는 인 구가 관련업종에 종사하고 있다.

필자는 2012년 4월 24일 이 단지에 소재한 台州大創 金屬有限公司(사장 林汝云)를 방문하여 리싸이클링현장 을 견학하였다. 약 4,000 평의 공장부지 양쪽에 지붕만 있는 건물이 길게 뺃어 있고(photo 6), 그 속에서 여러 가지 종류의 E-waste가 분해되어 철, 구리, 알루미늄,

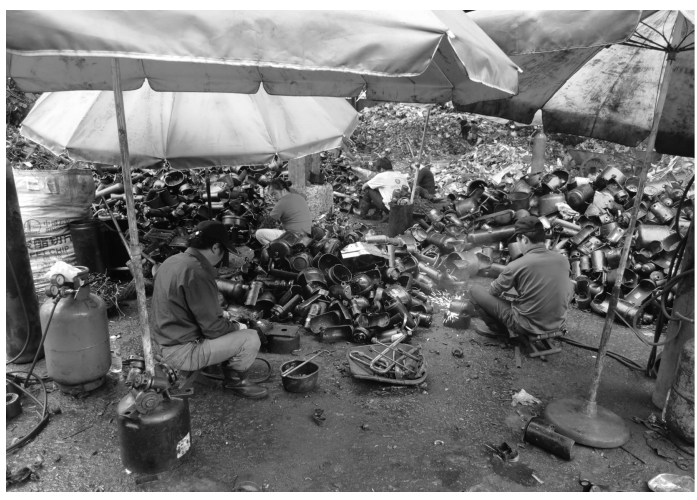

Photo 7. Dismantling of the waste motors.

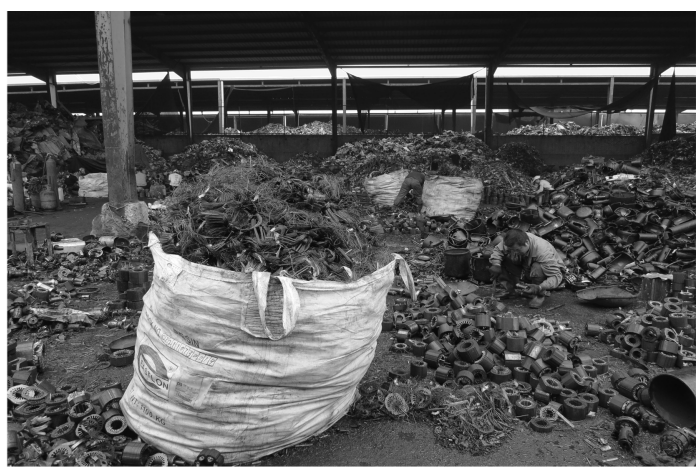

Photo 8. Recovery of copper wire from the waste motors.

주석, 플라스틱 등으로 선별되고 있다. 300명의 종업원 이 망치와 가스절단기 만으로 작업하고 있다. 정말 인 해전술 같다. $\mathrm{PCB}$ 는 별도로 수집하고 있다. 필자는 모 터의 분해 작업을 유심히 관찰하였는데, 가스절단기로 분 해(photo 7)한 다음, 구리전선을 회수(photo 8)하고 있었 다. 군데군데 자동차에서 회수한 하니스(harness)도 쌓여 있다. 모두 일본에서 수입한 것이라고 한다. 약 4,000 톤/ 월의 E-waste를 처리하고 있으며, 이 단지내 34 개 입주 회사 중에서는 이 회사가 중간 정도의 규모이다.

종업원은 청부제로 회수된 물품의 중량을 평가하여 임 금을 지불하고 있으며, 평균 수령액은 3,500-4,000元/ 월이 된다고 한다. 관리직은 6-7만기/년이다. 법정 최저 임금은 120 기일로 되어있다.

台州항구에는 제 1 부두와 제 2 부두가 있는데, 모두 E-waste가 산더미처럼 쌓여 있고 화물차에 상차가 한창 이었다(photo 9). 250만톤/년의 E-waste가 이 항구로 반 입되고 있다. 세계에서 년 3,000만톤의 E-waste가 중국으 로 반입되고 있으니, 台州시와 같은 항구 및 금속재생산 업단지가 12 개 이상 중국에 존재하고 있음이 짐작된다. 


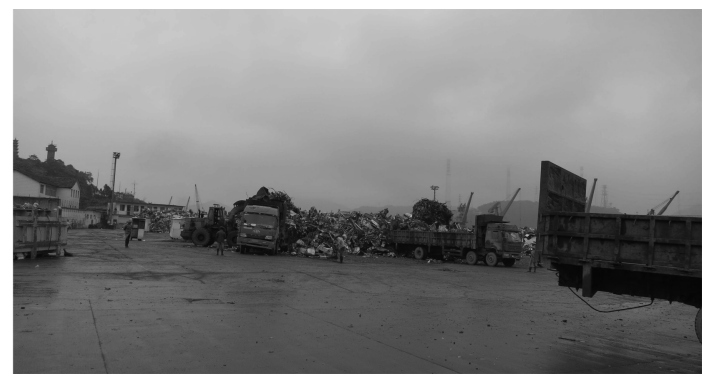

Photo 9. Overview of the Taizhou port.

\subsection{E-waste 해체리싸이클링 프로세스 - 廣東省 貴} 嶼 (Guiyu)의 예 ${ }^{6}$ -

廣東省 汕頭市 貴嶼鎭은 면적 $52 \mathrm{~km}^{2}$, 인구 13.9 만명 이고, 鎭 아래 27 개의 村이 있다. 貴嶼는 중국 E-waste 수도이고 세계에서 가장 큰 E-waste distribution center이다. 매년 貴嶼에서 해체 처리되는 E-waste 양은 기판 100 만톤, 부품 300 만톤이고, 2008년 E-waste 및 폐플라스틱의 회수·해체 처리가공에 의한 매상고는 20 억元(鎭 전체 공업 총생산액의 $90 \%$ )이며 납세액은 1,600 여만⿱一兀 이라고 한다. 휴대전화와 PC류의 E-waste 부품이 많고, TV와 냉장고는 거의 볼 수 없다.

貴嶼鎭 인민정부가 발표하고 있는 자료(2009. 12. 18)에서는 貴嶼鎭 전 지역에서 21村이 E-waste 해체가 공에 종사하고 있다. 그리고 300 개의 기업, 5,500 개의 개인 영업주의 종업원은 약 6 만명이다. 해체 작업공의
임금은 50元/일 정도이다. Fig. $6^{2}$ 은 貴嶼鎭에서의 Ewaste 처리 사진들이다.

(1) IC부품의 reuse

貴嶼지역에서 휴대전화의 기판 및 $\mathrm{PC}$ 의 하드디스크 로부터 IC부품을 회수 - 분류하고 있는 회사가 수십개 있다. 각지에서 컨테이너로 운반된 기판을 $50 \sim 60$ 元 $/ \mathrm{kg}$ 로 매수하고 있다. 휴대전화의 액정, 스피커, 키보드(플 라스틱), 기판의 3 극관 등을 회수하고 있다. 회수한 IC 부품은 타 회사원이 reuse가 가능한가 테스트(약 $20 \%$ 가 reuse 가능)한 후 분류해서 보관하고 있다. 회수한 $\mathrm{IC}$ 부품은 주변의 장난감 공장에 제공되고, $\mathrm{IC}$ 회수 후의 기판은 외지인(주로 호남省)에게 매각한다.

(2) 금속 회수

2006년 貴嶼에 동제련소가 건설되었다. 총투자액 1억 元, 대지면적 30 만 $\mathrm{m}^{2}$, 종업원은 100 명이다. 수작업으로 분해된 기판을 용련, 전해정련해서 6,000 톤/년의 동 인 고트(ingot)를 생산하고 습식야금법에 의해서 금·은 등 의 귀금속을 회수하고 있다.

Fig. 7에 貴嶼에서의 동정련 흐름을, Fig. 8에 습식처 리 흐름을 도시하였다. 반사로(처리능력 50 톤/일)에서 $97 \%$ 이상의 동을 얻고, 전해정련에서 $99.7 \%$ 이상의 전해동을 생산하고 있다. 슬래그 중에는 $10 \%$ 이상의 $\mathrm{Sn}$ 이 $\mathrm{SnO}_{2}$ 상태로 함유되어 있고 타지방의 정련공장에 운반되어 $\mathrm{Sn}, \mathrm{Pb}$ 가 회수되고 있다. Anode slime(陽極 泥)을 염산으로 처리해서 $\mathrm{Au}(70 \mathrm{~g} / \mathrm{t}), \mathrm{Ag}(150 \mathrm{~g} / \mathrm{t})$ 도 회수

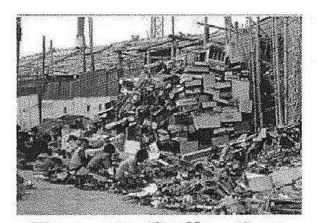

E-waste Collecting

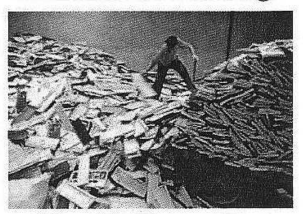

Plastic Recycling

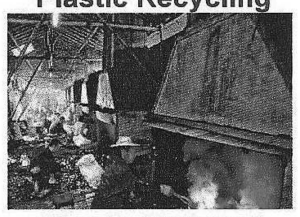

Plastic Removal

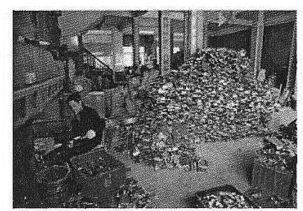

PCBs Collecting

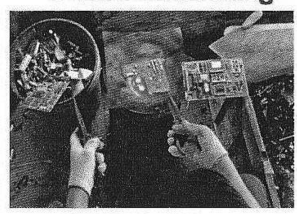

PCB Baking

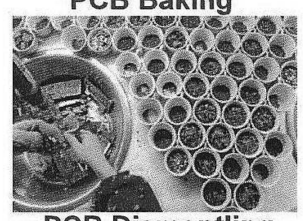

PCB Dismantling

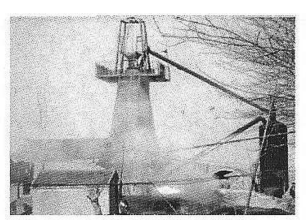

PCB Roasting

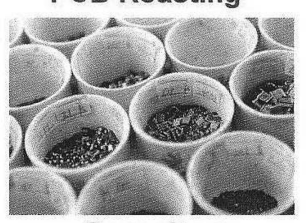

Capacitors

PCB Baking to remove solders PCB roasting to enrich the valuable metals

Fig. 6. E-waste treatment in Guiyu. 


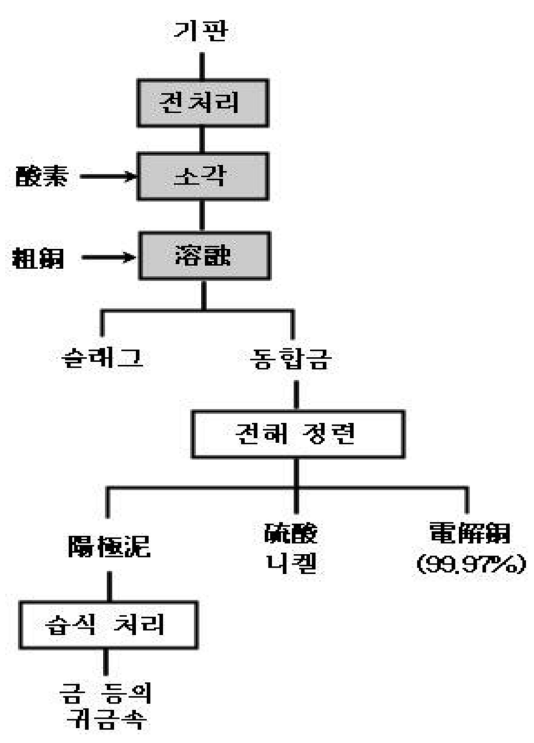

Fig. 7. Smelting process flow in Guiyu copper smelter.

하고 있다

(3) Informal recycling의 개선계획

貴嶼鎭은 2005년에 국가발전개혁위원회 등 6개 정부 부문으로부터 폐 - 중고가전 회수이용의 순환경제모델 지역으로 인정되었다. 모델사업은 폐수처리시설(처리능 력 3만톤/일), 쓰레기 소각발전시설(600톤/일), 쓰레기 무 해화 매립처분장의 건설 등이 포함되어 있다. 그리고 거 주지역을 신설하여 집중 거주시켰다. 貴嶼鎭 정부는 부 적정 리싸이클링업자를 단속해서 산으로 금속을 추출하 는 공장 58 동(면적 5.3 만 $\mathrm{m}^{2}$ ), 플라스틱 쓰레기 소각 40 동을 없앴다고 한다.

\section{4. 비철금속의 리싸이클링}

2010년 중국의 비철금속 총생산량은 3,135 만톤을 기 록하고 2015 년에는 42,000 천톤의 비철금속이 생산될 것 으로 예측된다. 그러므로 중국의 비철금속산업은 원료 부족과 고에너지소비 및 환경오염에 직면하고 있다. 이 문제점을 해결하기 위하여 적극적으로 비철금속의 리싸 이클링을 추진하고 있다. Fig. 97)는 1987년부터 2010 년까지 중국의 비철금속(9종류) 총생산량을 도시한 것 이다. 2000년도부터 비철금속 생산량이 급속히 증가하 여 2010년까지 10년간에 4배로 신장하였다.

Table $7^{7}$ )은 2003년부터 2010년까지의 중국 비철금속 9개 종류의 생산량이다. 동은 2010년도 479만톤을 생산

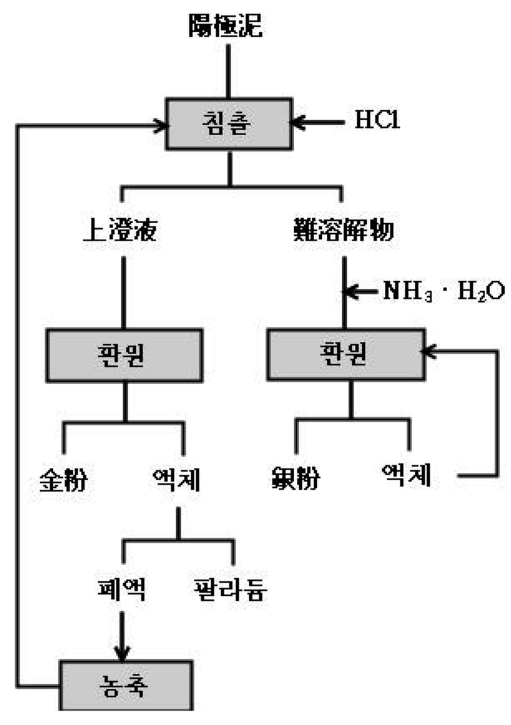

Fig. 8. Hydrometallurgical process flow in Guiyu copper smelter.

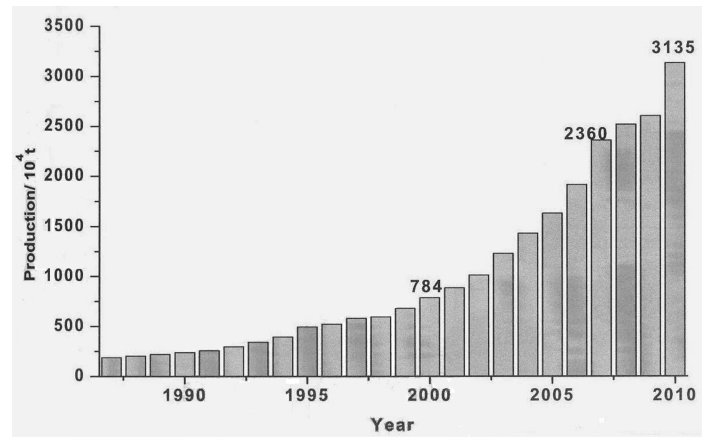

Fig. 9. Annual production of 9 main nonferrous metals in china(1987-2010).

하였다. 이 양은 중국 국민(13억 추산) 1 인당 $3.7 \mathrm{~kg}$ 에 해당된다. 만일에 선진국 수준 $(10 \mathrm{~kg} / 1$ 인 $)$ 의 동소비량을 가정한다면 약 1,300 만톤/년이 생산되어야 한다. 이 양 은 현재 세계 전체의 동소비량과 같다.

Fig. 107)은 년도별 동의 재생이용량, Fig. $11^{8)}$ 은 년 도별 알루미늄의 재생이용량, Fig. $12^{8)}$ 는 납의 년도별 재생이용량을 도시한 것이다. 2004년도 동의 재생이용량 은 50 만톤, 알루미늄의 재생이용량은 18 만톤, 납의 재 생이용량은 31 만톤으로 리싸이클링율 $\mathrm{Cu} 23 \%, \mathrm{Al}$ $2.7 \%, \mathrm{~Pb} 16 \%$ 로 산출된다. 일반적으로 리싸이클링율이 낮은 편이며 이는 낮은 금속축적량에 기인하는 것으로 생각된다. 
Table 7. Annual production of 9 main nonferrous metals in China(2003-2010)

\begin{tabular}{|c|c|c|c|c|c|c|c|c|c|}
\hline Item & Unit & & & & & & & & \\
\hline $\begin{array}{l}\text { Production of } \\
\text { main Product }\end{array}$ & $t \times 10^{4}$ & 2003 & 2004 & 2005 & 2006 & 2007 & 2008 & 2009 & 2010 \\
\hline Copper & $t \times 10^{4}$ & 183.63 & 219.87 & 260.04 & 299.89 & 349.69 & 370.87 & 410.95 & 479 \\
\hline Aluminum & $t \times 10^{4}$ & 554.69 & 668.88 & 780.60 & 934.9 & 1255.86 & 1317.63 & 1284.60 & 1565 \\
\hline Lead & $t \times 10^{4}$ & 156.41 & 193.45 & 239.14 & 273.55 & 275.74 & 325.79 & 370.79 & 420 \\
\hline Zinc & $t \times 10^{4}$ & 231.85 & 271.95 & 277.61 & 315.30 & 371.42 & 391.31 & 435.67 & 516 \\
\hline Nickel & $t \times 10^{4}$ & 6.47 & 7.58 & 9.51 & 10.77 & 11.58 & 13.26 & 16.48 & 21.4 \\
\hline Tin & $t \times 10^{4}$ & 9.81 & 11.53 & 12.18 & 13.81 & 15.13 & 12.95 & 13.45 & 14.9 \\
\hline Antimony & $t \times 10^{4}$ & 8.99 & 12.53 & 13.83 & 15.01 & 15.29 & 18.36 & 19.60 & 12.1 \\
\hline Magnesium & $t \times 10^{4}$ & 34.18 & 44.24 & 45.08 & 52.42 & 62.73 & 63.11 & 50.08 & 65.4 \\
\hline Titanium & $t \times 10^{4}$ & 0.41 & 0.48 & 0.92 & 1.33 & 3.05 & 4.14 & 6.15 & 6.6 \\
\hline Sum & $t \times 10^{4}$ & 1228 & 1430 & 1639 & 1917 & 2361 & 2520 & 2605 & 3135 \\
\hline
\end{tabular}

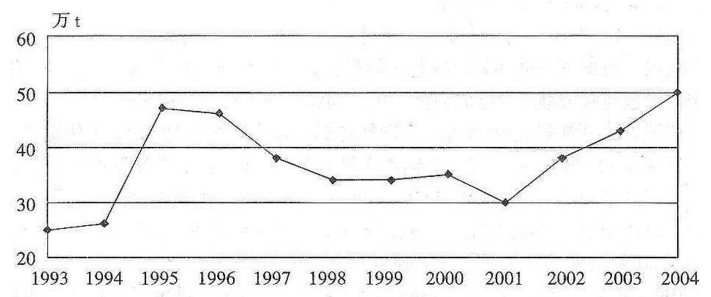

Fig. 10. Recycling of copper in China.

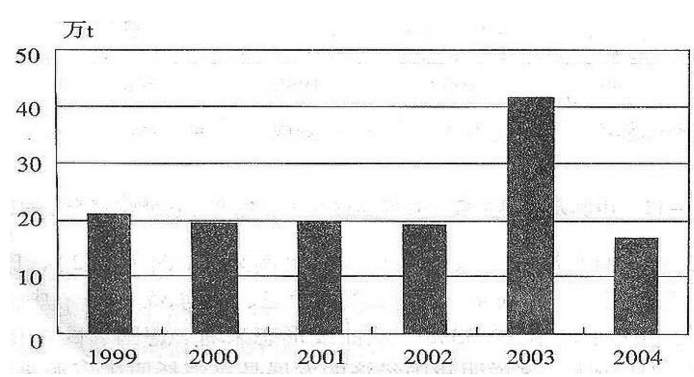

Fig. 11. Recycling of aluminum in China.

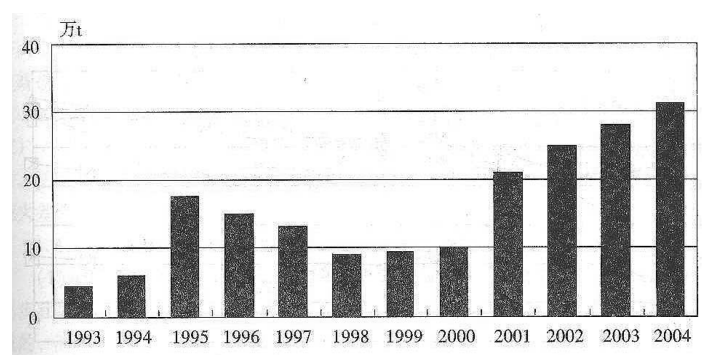

Fig. 12. Recycling of lead in China.

\section{5. 맺는말}

중국의 자동차 판매대수는 세계 1 위로 성장했고 수년 내로 폐차수도 대폭 증가할 것으로 예상된다. 경제발전 과 소득항상에 의하여 도시의 가전제품 보유대수는 선 진국 수준에 육박하고 있어 폐기제품의 적정처리와 리 싸이클링이 당면과제로 대두되고 있다. 한편, 중국정부 는 국가발전개혁위원회가 중심이 되어 법 - 제도의 재 검토와 확립을 추진하고 있다. 2005년 4월에 개정된 고 형폐기물 환경오염 방지법은 처음으로 생산자책임제도 를 도입하여 E-waste에 관한 생산자책임을 명문화하였 다. 2001년에는 ELV의 리싸이클링에 있어서 유일한 제 도인 폐기자동차 회수관리방법을 공포하였다. 이 외에 2003년 1월부터 시행된 청결생산 촉진법과 순환경제 촉 진법(2009년 시행)도 성에너지와 리싸이클링에 관련된 규정을 정하고 있다.

중국은 지역이 광대하고 도시와 농촌, 해안지대와 내 륙지대의 소득격차 등으로 리싸이클링 실상을 달리하고 있어 중국의 전체적인 리싸이클링 실태를 파악하기가 어렵다. 또한 E-waste의 대량 중국 유입이 환경오염의 우려를 낳고 있다.

\section{감사의 글}

본 연구는 국가청정생산지원센터의 에너지정보화 및 정책지원사업의 일환으로 수행되었으며, 본 연구를 지 원해주신 국가청정생산지원센터에 감사드립니다. 


\section{참고문헌}

1. 吉田 綾, 2008: 中國におけるリサイクル使用濟み家 電と自動車の事例-, アジアにおけるリサイクル, pp.223-253, IDE-JETRO, アジア經濟研究所, 日本.

2. Guo Xueyi(郭學葐), 2012 : Current recycling status of the E-waste in China, Workshop on E-wste Recycling in East Asia Proceedings, pp.4-24, Tohoku University, 日本

3. 劉庭秀, 2010 ：アジアにおける自動車リサイクル制度 の現狀と課題-韓國の運用狀況と中國の動向を中心に, 廢棄物資源循環學會誌, 21(2), pp.87-95, 廢棄物資源循 環學會

4. Park Chang hee(朴,昌熙), 2010 : A study on the scrapping

\section{吳 在 賢}

- 현재 연세대학교 명예교수

- 현재 한국자원리싸이클링학회 명예회장

•당 학회 제 10 권 5 호 참조 of vehicle's managing systems and developed countries effective recycling, MA THESIS, Fudan University.

5. 平岩幸弘, 2007 ：中國における自動車リサイクルの現 狀, 環境と公害, 36(4), pp.31-37, 岩波書店, 日本

6. 吉田 綾, 2010 : アジア地域における廢電氣電子機器 の處理技術の類型化と改善第の檢討(K2107), 2009年 度循環型社會形成推進科學研究費補助金 研究報告書, pp.51-54, 環境省, 日本

7. GuoXueyi(郭學盇), 2011 : Recent progress on resource recycling of nonferrous metals in China, 5th AustraliaKorea Joint Symposium Proceedings, pp.39-70, KIGAM.

8. 郭學盆, 田床華, 2008 : 有色金屬資源循環理論與方法, pp.37-41, 中南大學出版社, 中國.

金 俊 秀

- 현재 한국지질자원연구원 광물자원연구본부 책임연구원 - 당 학회 제 11 권 2 호 참조
閔 芝 源

• 현재 한국자원리싸이클링학회 실장 